\title{
Comparing a covered stand-off pad for on/off grazing during winter with conventional winter block grazing 2017-2019 at DTT Stratford Demonstration Farm
}

\author{
G.D. Pitman* \\ PGGWrightson Consultancy Taranaki \\ *Corresponding author: gpitman@pggwrightson.co.nz
}

\begin{abstract}
A two-herd farmlet comparison was carried out on the DTT Stratford Demonstration Farm in Central Taranaki to examine the profitability, environmental outcomes, animal welfare benefits and practicality of using a covered woodchip stand-off feed pad (Pad treatment) for wintering cows compared with leaving the animals on pasture (control). Use of the covered pad limited winter pugging damage to pasture to minimal levels, while $6 \%$ of the control farmlet requiring rolling and some re-seeding. Pasture growth on the pugged areas was 24 to $30 \%$ lower over spring and early summer. Estimated annual pasture growth was $2.2 \%$ higher on the Pad farmlet compared to the control over the two years. The mean difference in milk solids production over two years was $3 \%$, (range $:<1-5 \%$ ) in favour of the Pad herd. Calculated nutrient losses (OverseerFM) showed a $9 \%$ reduction in nitrogen leaching from the covered pad. Cost benefit analysis suggested that the use of the covered standoff in winter covered the annual operating cost of the stand-off pad but failed to contribute to the capital cost of providing this facility.
\end{abstract}

Keywords: Pasture, pugging, milksolids, profit, nitrogen leaching

\section{Introduction}

Since 2010 there has been an increasing trend for dairy farmers to build covered stand-off pads for wintering cows. This is particularly important in high rainfall and heavy soil areas. An estimated 70 to 100 farms in Taranaki ( $6 \%$ of farms) currently use pads with more planned (Redpath.co.nz, Smartshelters.co.nz). These are typically used for non-lactating rather than for milking cows. These pads have a capital cost between $\$ 1200$ to $\$ 2000 /$ cow plus an annual operating cost. In Taranaki, pads are mainly used in the higher rainfall zones $(1800 \mathrm{~mm}$ to $3500 \mathrm{~mm})$, high altitude $(250 \mathrm{~m}$ to $500 \mathrm{~m}$ ) and inland regions (especially around Stratford and Inglewood), which have wetter soils. Farmers generally aim to reduce pasture damage from pasture treading damage (pugging) during wet weather by utilizing supplementary feed along with the use of lower cost feedstuffs to achieve longer lactation periods and higher milk yields.
The effect of winter pugging on subsequent grass growth is visually apparent but has not been extensively measured in recent years. A trial at the Taranaki Agricultural Research Station in 1984 (Thomson and Laurence 1992) under moderate rainfall of $25 \mathrm{~mm}$ for 5 days and with no visual difference in pugging, saw no effect on regrowth over the subsequent four months from a 4 hour on/off grazing system compared to zero grazing harvesting (cut and carry). There was a $17 \%$ decline in pasture growth for 24-hour block grazing and a $29 \%$ decline during 5 days strip grazing with no back fence. Other studies have found up to $60 \%$ less regrowth from high stocking density and long grazing durations (Beukes et al., 2013), including less productive pasture species and more weed invasion. A review by Glassey (2019) determined that whole farm annual pasture growth reduction due to pugging was in the 1 to $3 \%$ range, which is well below farmer estimates of $10 \%$ or more. A $10-30 \%$ improved feed utilization has been claimed for animals on feed pads compared to paddock access (DairyNZ Facts \& Figures 2017), with up 35\% improved feed efficiency suggested in one report (Woodford 2018). More recent trials and evaluations (Pastoral 21 report, DairyNZ, MacDonald et al., 2014, Journeaux and Newman 2015) on the use of wintering shelters and barns have examined the overall effect of systems with variable input differences rather than comparing the direct difference between use of the pad or no pad, with all other inputs equal. In a comparison, over 8 years at Massey University, McQueen (1970) found a $3 \%$ increase in milk production but no economic benefit in using a covered winter barn and feed pad for wintering cows.

In addition to any milk and pasture benefits, there are assumptions that feed requirements will be lower and will be more efficiently used by cows kept in a covered shelter. Some have claimed animal health and environmental benefits from feed pads and there has been some pressure for farmers to use such facilities for these reasons.

A two herd farmlet comparison was set up on the Dairy Trust Taranaki Stratford farm, which had a covered pad, and was used in 2017-18 and 2018-19 to examine the effects of using the pad for on-off winter grazing compared to paddock only, where all other inputs were equal. 


\section{Materials and methods}

The two herd farmlet comparison commenced in June 2017 and continued for two seasons, finishing in May 2019. The farm is located on the eastern boundary of Stratford in central Taranaki. It has a flat contour with sandy loam volcanic ash soil, which is relatively free draining. The farm is 290 metres above sea level and has an annual rainfall of $2040 \mathrm{~mm}$ where 140 rain days are over 1mm. (NIWA station Stratford E94334). The rain is moderately spread over the year, but generally less in the mid-late summer. Rainfall over the May to August period averaged $207 \mathrm{~mm}$ per, and 15 days per month had more than $1 \mathrm{~mm}$. The highest recorded monthly winter rainfall is $542 \mathrm{~mm}$ in July 1974. Sunshine hours average 118 hours per month for the May to August period. Pastures were standard ryegrass clover mix but include other grasses and weeds.

\section{Farmlet 1 - Control group ( 25 ha., 82 cows)}

A high producing, mainly self-contained, all grass system (with replacement stock grazed off) at a stocking rate at 3.3 Jersey cows/ha was used as the control group. This was determined as being the economic optimum for a self- contained system from previous trials on the Demonstration Farm and has been used as a long-term control farmlet system in previous trials.

\section{Farmlet 2 - Pad ( 25 ha., 82 cows)}

A farmlet at the same stocking rate as the control and with equal inputs, but with a covered woodchip standoff pad used for holding the dry cows off pasture every night over the winter including calving, comprised the treatment (Pad) group.

\section{General management}

The paddocks on the farm were randomized, so each group was spread over the entire farm and had an equal balance of old and newer pastures. The herds is a high breeding worth (BW; 107 at 2017) Jersey herd with a mid-season liveweight of $400 \mathrm{~kg} / \mathrm{cow}$. The herds were selected be equal, based on age, BW, production worth (PW), weight, condition score and calving date, and cows remained in the same herd for both years. Each year, in-calf heifers were randomised by BW and liveweight, and brought into each herd at a $20 \%$ replacement rate. Heifers were kept separate from the main herd until June $1^{\text {st }}$ and then joined and grazed as one herd per farmlet through the winter. The planned start of calving for both herds was $1^{\text {st }}$ August, with breeding and animal health management the same for each herd. Replacement yearlings were grazed off site on a May-to-May basis, and calves were grazed off site from mid-summer onwards.

The farmlets were set up to have equal starting pasture cover and similar feed from June 1 2017, and herds were managed to be fed at a similar level during winter with the same supplementary feed types and amounts. For the second winter, late autumn-early winter management was designed to set each farmlet up with similar pasture cover and feed as the previous winter by early June.

Both herds were offered daily winter allowances of pasture by break feeding at a stocking density of 21$23 \mathrm{~m}^{2} / \mathrm{cow} /$ day, equating to a 130-day rotation. The control herd remained on their paddock break for 24 hours, except in extremely wet conditions, when they were given extra area or stood off on the race or yards overnight. This only occurred on 5 to 7 days each winter. The Pad group was allocated the same area of grass per day as the control and were moved to the covered pad for the night, generally spending 8 hours on pasture and 16 hours on the pad. However, in wet conditions they only had 3 or 4 hours on the pasture and 19-20 hours on the pad. Occasionally, if wet in the morning, the cows stayed on the pad until later in the day or had all day on the pad and had an extra grass break the next day. Hay and silage were fed out to the control herd dry cows in the paddock and on the covered pad after the Pad group had received their grass break, with equal amounts fed to each group each day. The Pad dry cows used the pad every night after drying off and this continued to nearly the end of calving. Cows at calving were not separated from the rest of the herd. During lactation, the herds were on generally equal rotation periods, with surplus pasture identified and harvested as silage.

Lactating cows in each group remained on pasture and were fed palm kernel expeller (PKE) which was fed at equal rates from start of calving until late September, when grass levels were deemed adequate or as needed during deficit periods during the rest of the milking season. PKE for lactating cows in the Pad group was fed out onto the covered pad and to the control herd in troughs on the exit race following milking. PKE was fed at equal rates to each herd each day used. Any other feed, such as hay and silage, were fed at equal levels and times for both groups. Any areas of pasture that were pugged were rolled where required, and when possible, and severely pugged areas were sown with new seed.

Fresh woodchips at $1.2 \mathrm{~m}^{2} / \mathrm{cow}$ were spread on the pad in mid-May and were stirred two to three times per week with a tyne cultivator. The pad was cleaned to a depth of around $20-30 \mathrm{~cm}$ in the 2018 autumn, which was three years since the previous cleaning, and the discarded material spread on the Pad farmlet.

\section{Measurements and monitoring}

Pasture cover and yield measurements were assessed using visual assessment, via a calibrated plate meter on a one to two weekly basis. Milk solids were recorded in 
separate milk vats for each farmlet, with monthly herd testing for each individual cow (LIC). The cows were weighed and condition scored every four to six weeks and were dried off and managed in the autumn aiming to have both herds with equivalent average condition and weight by June $1^{\text {st }}$. Animal health indicators and mating results were recorded for each herd. Pasture pugging was recorded in each paddock through the winter using the PPPP (Pitman Pasture Pugging Points) scale of 0 to 5 , where 0 was no notable treading effect, 1 light, 2 light moderate, 3 moderate pugging and ideally needs rolling, 4 pugging which needs rolling and reseeding and 5 severe pugging which needs re-grassing.

\section{Statistical methods}

Due to lack of replication and having just two years of results, milk production and pasture production results were not statistically analysed. Results are therefore presented as a quantitative case study using raw means. Individual cow milk production collected by herd testing was not analysed. Individual winter cow weight and body condition were analysed, but the differences were not statistically significant.

\section{Results and discussion}

The 2017 winter started off dry, with June rainfall being only $74 \mathrm{~mm}$ and $37 \%$ of the average. July to September was very wet, with $932 \mathrm{~mm}$ of rain $(158 \%$ of the seasonal average) The 2017 spring was dry, with below average pasture growth, but growth was good from mid-summer onwards. Winter 2018 rainfall was below average rainfall for June, average for July and August, below average for September to February, with the latter being very dry ( $20 \%$ of average). Autumn 2019 rainfall was average or above. Over the two seasons, planned extra feed included PKE to cover the calving to late September period, however extra feed was purchased in both seasons to cover the deficit due to dry weather during the 2017 late spring and 2019 summer. Brought in feed averaged $511 \mathrm{~kg} \mathrm{DM} /$ cow and $1676 \mathrm{~kg} \mathrm{DM} / \mathrm{ha}$ per year.

\section{Pasture cover}

Both groups started with equal pasture cover levels in June 2017 and were fed the same amount of pasture and supplemental feed throughout the winter, other than if the control group were given extra grass on wet days. At the start of calving, the control farmlet pasture cover was $366 \mathrm{~kg} \mathrm{DM} / \mathrm{ha}$ less than June $1^{\text {st }}$ cover and the pad farmlet $299 \mathrm{~kg} \mathrm{DM} / \mathrm{ha}$ less, giving a $67 \mathrm{~kg} \mathrm{DM} /$ ha advantage to the Pad farmlet. For the second winter, pasture covers and supplement levels were equal by early June. By the start of calving 2018, the control farmlet cover was $378 \mathrm{~kg} \mathrm{DM} / \mathrm{ha}$ less than June 11 and the Pad farmlet $315 \mathrm{~kg}$ less, giving a $63 \mathrm{~kg} \mathrm{DM} /$ ha advantage to the Pad farmlet. The measured grazing residuals throughout the winter were at similar levels. Hence, the extra pasture cover for the Pad herd was assumed to be a result of better pasture growth and/or the control herd effectively having a 5 to 6 days quicker winter grazing rotation due to the cows being given extra area on wet days.

Over the 2017-18 season, from calving to drying off, the Pad farmlet pasture cover was equal or more than the control through to mid-spring, allowing more surplus for silage. Pasture covers were nearly equal for the rest of the season. For the 2018/19 season, pasture covers from the end of calving were nearly equal all year, with higher initial cover at calving on the Pad farmlet.

\section{Pasture growth}

There were small differences in pasture growth over the 2017-18 season, with the Pad herd slightly ahead at $406 \mathrm{~kg}$ extra DM/ha grown (15364 vs. $14958 \mathrm{~kg} \mathrm{DM} /$ ha, $+2.7 \%$ ). During the 2017-18 season, pasture growth was $229 \mathrm{~kg} \mathrm{DM} / \mathrm{ha}$ (14437 vs. $14662 \mathrm{~kg} \mathrm{DM} / \mathrm{ha},+1.6$ $\%$ ) resulting in $+2.2 \%$ extra growth across two seasons.

In the first year, $28 \%$ of the farmlet area for the pad herd was harvested (128 kg DM/cow) as surplus for silage in the spring, while on the control farmlet $17 \%$ of the area was harvested ( $92 \mathrm{~kg} \mathrm{DM} / \mathrm{cow}$ ). These levels were relatively low compared to usual harvest expectation. In the second season, both farmlets harvested $31 \%$ of the available pasture area, which was at a more expected level with 252 and $255 \mathrm{~kg} \mathrm{DM} / \mathrm{cow}$ for the control and pad herds respectively.

\section{Body weights and condition score}

At the start of the trial period, all cows were similar in weight and body condition score. Over the first winter the control herd gained $15 \mathrm{~kg}$ in weight, but had no change in condition score, while the Pad herd gained $22 \mathrm{~kg}$ in weight and 0.3 increase in body condition score. By November, there were minimal differences between the herds. Over the second winter, the control herd gained $19 \mathrm{~kg}$ in weight and 0.23 in condition score, while the Pad herd gained $36 \mathrm{~kg}$ in weight and 0.37 in condition score, so had better body weight and slightly better condition at the start of calving, although the difference was not statistically significant. Over the remaining season there were minimal differences between the herds.

The body weight and condition score changes were consistent with expected responses (DairyNZ, 2017), likely due to a reduction in wastage from feeding supplements on the stand-off area. If the cows were fed $3 \mathrm{~kg} \mathrm{DM} / \mathrm{cow}$ for 80 days this equalled $240 \mathrm{~kg} \mathrm{DM}$ in total. A $10 \%$ theoretical improved feed efficiency from using the stand-off area equals $24 \mathrm{~kg}$ DM extra feed 
utilised per cow. At $130 \mathrm{~kg}$ DM required per condition score increase, an extra $24 \mathrm{~kg}$ DM would result in a 0.2 increase in condition. This result, however, could have been due to a combination of better supplement use and lower intake requirement from the benefit of indoor shelter.

\section{Milk solids production}

Table 1 shows the results relating to milk solids production overall and for both seasons.

The 2017-18 vat milk production per cow from the pad herd was higher than the control during September and October, but near equal up to the start of May, when the control herd was dried off. At this point, the pad herd had a $10 \mathrm{~kg} \mathrm{MS} / \mathrm{cow}$ (or 3\%) advantage over the control group and an extra six says in milk (DIM), due to having extra silage available resulting in the Pad herd producing a further $6 \mathrm{~kg} \mathrm{MS} / \mathrm{cow}$, resulting in $16 \mathrm{~kg} \mathrm{MS} / \mathrm{cow}$ (or 5\%) more than the control herd, in total (336 kg vs. 320kg). During the second year, milk production per cow was generally the same, except for two short periods, when the control herd was ahead. The Pad herd had a faster calving rate, resulting in an extra 5.5 days in milk, and production per ha was higher during the early to mid-spring period. The Pad herd had more issues in the autumn, with lower condition cows needing earlier drying off, resulting in lower late autumn per ha production. In the second season, the Pad herd produced $3 \mathrm{~kg} \mathrm{MS} / \mathrm{cow}(355 \mathrm{~kg}$ vs. 352 $\mathrm{kg}$ ) and $10 \mathrm{~kg} \mathrm{MS} / \mathrm{ha}$ ahead of the control, giving a $1 \%$ advantage. Over the two years this equalled a $2.75 \%$ overall advantage in milk production for the pad herd. Small differences between the two herds meant that statistical analysis using the individual cow herd test data was not carried out.

\section{Animal health and mating}

Over the two periods, the control herd had more lameness (11 vs. 7 cases) and mastitis treatment (13 vs. 5 cases) than the pad herd with the higher control herd level, mainly due to ongoing individual cases. Other animal health treatments were similar between the herds. Somatic cell count was low and similar for both herds $(111,000$ vs. 118,000), which indicated no detrimental effect from pad use

Recorded calf deaths at parturition were higher for the control herd compared to the Pad herd (seven $v s$. three) during 2017, but similar, (six vs. seven), during 2018 calving. Cow deaths were similar between the herds over the two years (six $v s$. five).

In the first season, controlled internal drug release (CIDR) use in non-cyclers was higher for the control herd $(11 \% v s .7 \%)$, but levels were low in both herds. During the second year, no CIDR treatment was used. The four-week submission rates were $4 \%$ higher for the pad herd ( $89 \%$ vs. $93 \%)$ The 'not in calf' rate was $1 \%$ point lower for the pad herd ( $11.5 \%$ vs. $10.5 \%)$, while the six week in-calf rates were similar, at $76 \%$. The Pad herd had quicker initial calving in the second year as a result of the first season mating outcomes, acquiring 5 days in milk extra per cow.

\section{Pasture pugging}

Pasture pugging levels were assessed and recorded for each paddock throughout the winter. This was on the Pitman Pasture Pugging Points (PPPP) scale of 0 to 5, where 0 showed no notable treading effect, 1 light, 2 light moderate, 3 moderate pugging and needed rolling, 4 pugging which needed rolling and re-seeding and 5 severe pugging which needed full re-grassing. Table 2 shows the results over the two winter periods.

In 2017 , the control farmlet had $42 \%$ of its total area showing some pugging, but only $6 \%$ was severe. (score 4-5). For scores of 3 to 5 , there were 22 pugging events per winter. On the Pad farmlet, $20 \%$ of the area had some pugging, of which only $2 \%$ was severe. In 2018, the control farmlet had pugging on $30 \%$ of the farm area, with $6 \%$ being severe which required rolling and re-seeding in parts. The Pad farmlet had just under $4 \%$ of the area being pugged, of which $1 \%$ was severe. In 2017 , minimal rolling was done on the severely pugged areas, as it was too wet until October and then became too dry. In the second winter (2018), $10 \%$ of the farmlet had to be rolled. The areas that scored 5 were mainly small, and predominantly where the cows spent the night in a corner of the paddock.

On the Pad farmlet, most pugging was seen on access ways where the cows were moved to and from the

Table 1 Milksolids production as measured from vat collection for each year and overall mean

\begin{tabular}{|c|c|c|c|c|c|c|c|}
\hline \multirow[b]{2}{*}{ Year } & \multicolumn{3}{|c|}{ Control } & \multicolumn{3}{|c|}{ Pad } & \multirow{2}{*}{$\frac{\text { Pad-Control }}{\text { Mean \% change }}$} \\
\hline & 2017-18 & 2018-19 & Mean & 2017-18 & 2018-19 & Mean & \\
\hline Cows & 83 & 81 & 82 & 83 & 81 & 82 & \\
\hline MS/cow (kg) & 320 & 352 & 336 & 336 & 355 & 345.5 & $2.75 \%$ \\
\hline MS/ha (kg) & 1063 & 1140 & 1101.5 & 1115 & 1150 & 1132.5 & $2.75 \%$ \\
\hline Days in milk/cow & 247 & 252 & 249.5 & 251 & 255 & 253 & $1.4 \%$ \\
\hline
\end{tabular}


covered pad to the paddock. In winter on this farmlet (23 paddocks) the cows had 5 to 6 days grazing per paddock, on average, with access alley ways requiring rolling but not re-seeding. The area needing re-seeding on the control farmlet was 1.6 ha ( $6 \%$ of the total area) compared to $4 \%$, which was typically done on the farm historically. Over the two winters there were 22 days on average where pugging events scoring 4 or 5 occurred.

Pasture growth was measured at different levels of pugging on pasture breaks in certain paddocks. These areas were assessed using a rising plate meter during the weekly farm walks throughout the spring and early summer. The results, although not statistically analysed, indicated no pasture growth difference between areas with pugging scores of 1 and 2 . The difference between no pugging and score 4 was $24 \%$ to $30 \%$ less growth. At $15,000 \mathrm{~kg} \mathrm{DM} / \mathrm{ha}$ annual growth, $30 \%$ less equalled $4,500 \mathrm{~kg} \mathrm{DM} / \mathrm{ha}$. With $6 \%$ of the farm growing $30 \%$ less, this equalled $2 \%$ less growth over the whole farm, which was similar to the overall growth differences measured. However, pasture growth on the pugged areas in the summer and autumn, and in subsequent years, was not assessed.

During August 2018, two paddocks side by side with generally identical conditions and history were grazed at the same time during moderately wet weather and one very wet night. The PPPP for the control farmlet paddock breaks were scored at 2, 3, 0, 4 and 2 while the Pad farmlet paddocks had scores of 0 or 1 . Pasture growth was measured on different control paddock breaks until early January. Those that scored 3 and 4 grew $24 \%$ less than those with 0 and 2 scores. Over the whole year, the growth from Farm IQ records from each paddock was $14.52 \mathrm{t} \mathrm{DM} /$ ha for the control and 15.65 for the pad paddocks. This equalled $7 \%$ extra growth in the pad paddock, which was consistent with the one extra milking achieved off the paddock.

\section{Covered winter pad management}

The covered winter pad was a standard metal framed Redpath design with a translucent covering on the roof and a shade cloth wind break on the sides and open at the ends. It had two $60 \mathrm{~m} \times 9 \mathrm{~m}$ bays with an internal central lane and a concrete feed trough. The herd used one side per night and the same side for most of the winter, which equalled $6.5 \mathrm{~m}^{2} /$ cow. Occasionally, both sides were used if needed in very wet weather and during calving.

The base land area of the pad was unlined and tile drained to a collection tank. When built in 2012, there was a $20 \mathrm{~cm}$ base layer of wood bark and peelings applied and $40 \mathrm{~cm}$ of wood chips applied on top, with the intention of replacing the top 10 to $20 \mathrm{~cm}$ of wood chips each year. In practice, the pad was cleaned every 3 years, but had fresh wood chips $\left(1.2 \mathrm{~m}^{3} / \mathrm{cow} /\right.$ year of chipped wood pellets) applied at the start of each winter during the trial (15-20 cm depth of fresh wood chips). The pad was stirred with a tyne cultivator two or three times per week.

In the first few years of use of the pad prior to this trial, there was minimal water and effluent collected in the drainage tank, the exception being when there was a strong northerly wind with rain. The shade cloth sides stopped some of the rain, but it still misted through and made the pad wet, causing a mess similar to a pugged paddock. Side eves were installed on the north side to stop the rain getting in, and the pad remained dry with almost no water collected in the drainage tank. In winter moderate sunshine allowed drying the base layer and it was assumed that most moisture evaporated rather than draining out. The cows were on the pad for 16 hours per day after 8 hours on pasture and were fed supplements in the feed troughs. However, on wet days, they may have had 3 or 4 hours on pasture and up to 20 hours on the pad. Occasionally, if wet in the morning, they remained on the pad and received supplemental

Table 2 Pasture pugging levels (PPPP score 0-5) for two winter periods in dairy herds with and without feed pad access, expressed by measured area (ha) and percentage of total farm area.

\begin{tabular}{|c|c|c|c|c|c|c|c|c|}
\hline \multirow[b]{3}{*}{ PPPPscore } & \multicolumn{4}{|c|}{ Control } & \multicolumn{4}{|c|}{ Pad } \\
\hline & \multicolumn{2}{|c|}{2017} & \multicolumn{2}{|c|}{2018} & \multicolumn{2}{|c|}{2017} & \multicolumn{2}{|r|}{2018} \\
\hline & Area (ha) & $\%$ farm area & Area (ha) & $\%$ farm area & Area (ha) & $\%$ farm area & Areas (ha) & $\%$ farm area \\
\hline 1 & 3.58 & 14 & 0.6 & 2.4 & 3.7 & 15 & 0 & 0 \\
\hline 2 & 2.6 & 10 & 4.3 & 17 & 0.4 & 2 & 0.02 & 0 \\
\hline 3 & 3.2 & 13 & 1.3 & 5 & 0.4 & 2 & 0.7 & 0.03 \\
\hline 4 & 1.58 & 6 & 1.0 & 4 & 0.38 & 2 & 0.23 & 1 \\
\hline 5 & 0.64 & 0.03 & 0.5 & 2 & 0.01 & 0 & 0 & 0 \\
\hline Total & 10.6 & 42 & 7.4 & 30 & 4.9 & 20 & 0.95 & 3.8 \\
\hline
\end{tabular}


feed, and then were either moved out to pasture grazing later or remained on the pad and had extra pasture the following day. After consuming their feed, the cows were able to lay down on the pad, which was used until the end of calving. The cows remained in the main herd and calved in the group with no problems. When the herd was out in the paddock, the calved cows remained behind on the pad with their calves until a more suitable time allowed for their organization.

The pad was cleaned near the end of the first season of the trial removing the top 20 to $30 \mathrm{~cm}$ above the original bark/peelings layer, which was spread at a rate of $6 \mathrm{t} / \mathrm{ha}$ covering $60 \%$ of the farmlet. Random samples of the bedding were analysed and comprised $48 \%$ moisture, $\mathrm{pH} 8.4, \mathrm{C} / \mathrm{N}$ ration 17.5 and on a wet weight basis total $\mathrm{N} 0.96 \%$, total C $17 \%$, phosphorous $0.45 \%$, potassium $2.0 \%$, sulphur $0.33 \%$ and calcium $0.83 \%$. One quarter of the volume was dried wood chip and the remainder cow manure and broken-down wood. The pasture application rate equalled $60 \mathrm{~kg} \mathrm{~N} / \mathrm{ha}, 27$ $\mathrm{kg} \mathrm{P} / \mathrm{ha}, 120 \mathrm{~kg} \mathrm{~K} / \mathrm{ha} 20 \mathrm{~kg} \mathrm{~S} / \mathrm{ha}$ and $50 \mathrm{~kg} \mathrm{Ca} / \mathrm{ha}$, and there was a $10 \%$ increase in pasture growth over the six weeks following application compared to similar paddocks based on the weekly farm walk data. The pad was cleaned near the end of the first season of the trial removing the top 20 to $30 \mathrm{~cm}$ above the original bark/peelings layer, which was spread at a rate of $6 \mathrm{t} /$ ha covering $60 \%$ of the farmlet. Random samples of the bedding were analysed and comprised $48 \%$ moisture, $\mathrm{pH} 8.4, \mathrm{C} / \mathrm{N}$ ration 17.5 and on a wet weight basis total $\mathrm{N} 0.96 \%$, total C $17 \%$, phosphorous $0.45 \%$, potassium $2.0 \%$, sulphur $0.33 \%$ and calcium $0.83 \%$. One quarter of the volume was dried wood chip and the remainder cow manure and broken-down wood. The pasture application rate equalled $60 \mathrm{~kg} \mathrm{~N} / \mathrm{ha}, 27 \mathrm{~kg} \mathrm{P} / \mathrm{ha}, 120$ $\mathrm{kg} \mathrm{K} / \mathrm{ha} 20 \mathrm{~kg} \mathrm{~S} / \mathrm{ha}$ and $50 \mathrm{~kg} \mathrm{Ca} / \mathrm{ha}$, and there was a $10 \%$ increase in pasture growth over the six weeks following application compared to similar paddocks based on the weekly farm walk data.

\section{Labour and machinery use}

The time input for feeding supplements and moving stock on the control farmlet was similar to feeding supplements and walking the cows to and from the pad. The pad is in a central location on this farm. Extra time was needed to bring the cows in to the pad in the afternoons, although a timed gate release mechanism could be used to reduce this. One of the benefits of the covered pad was at calving time, as it was near the milking shed and easy to check cows at night, if required, and in the morning and attend to any issues as required.

The pad required extra tractor and labour time for stirring the woodchips ( 8 hours per winter) plus machinery and labour in spreading the woodchips at the start of the winter (3 hours). Cleaning out the pad and spreading on paddocks was done entirely by a contractor. For the control farmlet, extra time and tractor use was required for rolling and reseeding pastures (9 hours per winter). No assessment was made for labour differences at calving time. It was assumed that there would be minimal difference in machinery between the two systems as both require a similar feed out wagon for silage and hay, whether feeding on the pad or on pasture. The only extra machinery required for the pad was the tyne cultivator, which was of relatively low cost.

\section{Nutrient losses and management}

One of the assumed benefits for using stand-off pads is to reduce nutrient losses, especially nitrogen leaching during the winter. (de Klein and Ledgard 2001) This could be achieved with an uncovered pad but would need to be fully drained to effluent ponds or containment systems. A covered pad reduces effluent volume significantly. Stratford's winter rainfall of 800 $\mathrm{mm}$ over four months, means that $8 \mathrm{~m}^{2}$ of pad area would collect 6400 litres per cow of rain along with

Table 3 Overseer nutrient budget calculations (average over two seasons)

\begin{tabular}{lcc} 
Farmlet & Control & Pad \\
\hline N loss/ha & 74 & 67 \\
P loss/ha & 1.9 & 1.9 \\
NCE \% & 27 & 27 \\
GHG eCO2 t/ha & 13.2 & 13.6 \\
\hline
\end{tabular}

\section{Economics}

Partial budget ( per cow basis)

Income

Extra milk production

10 kg ms/cow @ \$7 $\$ 70$

Expenditure for winter pad

(annualized cost)

Woodchips

1.3 m³/cow @ \$33

43

Base wood chip replacement

(10 yearly)

8

Pad cleaning

10

Repairs \& maintenance general

5

Roof cover replacement (10 yearly)

12

Pad stirring and woodchip spreading 8

Extra silage making cost $1^{\text {st }}$ year 3

Total extra cost $\quad \$ 89$

Saved cost re-grassing and rolling $\$ 20$

Net return

Capital(Interest \& depreciation) $\quad \$ 1100 /$ cow at $8 \%$

Net cost \$/cow

$\$ 88$

$\$ 87$ 
effluent. This would require a substantial increase in the farm's containment area, which could equal the cost of covering the pad at $\$ 600 /$ cow. In addition, more woodchips would be required if left uncovered.

The two-year trial data were analysed in the OverseerFM nutrient budget programme (v. 6.3.4; www.overseer.org.nz). This was based on farm dairy effluent being spread evenly over the farmlets for both feeding systems and winter pad cleanings spread evenly over the farmlet each season. OverseerFM calculated overall average $\mathrm{N}$ losses of 74 and $67 \mathrm{~kg} \mathrm{~N} /$ ha for the control and Pad herds, respectively, which represented a $7 \mathrm{~kg} \mathrm{~N} / \mathrm{ha}$ or $9 \%$ reduction (Table 3). An additional reduction of $2 \mathrm{~kg} \mathrm{~N} / \mathrm{ha}$ was calculated if the pad cleanings were spread in the spring rather than the autumn. There was no difference in P losses calculated between the farmlets.

From these results, extra milk production income covered the running costs of the covered winter pad, but not the initial capital cost, however, there were some benefits from improved breeding results. Farmers using covered winter pads often justify the cost by using lower price supplements that cannot be practically feed in paddocks. Farmers feeding supplement to milkers can also use the covered pad rather than building a separate feed pad, thus utilising the capital expense twice.

\section{Conclusions}

The extensive use of a covered woodchip feed pad in Central Taranaki for on/off grazing wintering resulted in minimal winter pasture pugging, increased pasture growth improved calving cow weights and body condition. This resulted in a $3 \%$ increase in milk production, an improvement in mating and a $9 \%$ reduction in calculated nitrogen leaching. There was little difference in animal health and assessed labour input. The calculated financial benefits only covered the operating cost of the covered pad, but not the capital cost. Famers using these structures often value them for 'peace of mind' wintering to avoid pasture pugging and find them beneficial at calving time. They also use them to utilize lower cost supplementary feeds, which cannot be fed in paddocks, and often see longer lactation duration and higher milk production.

\section{ACKNOWLEDGEMENTS}

The DDT Stratford Demonstration Farm received time input from DairyNZ in the process of this trial and especially from Chris Glassey in writing this summary which is greatly appreciated. The input of Farm Manager Paul Henwood is acknowledged.

\section{REFERENCES}

Beukes PC, Romera AJ, Clark DA, Dalley DE, Hedley MJ, Horne DJ, Monaghan RM, Laurenson S 2013. Evaluating the benefits of standing cows off pasture to avoid soil pugging damage in two dairy farming regions of New Zealand. New Zealand Journal of Agricultural Research, 56(3): 224-238. https://doi.or g/10.1080/00288233.2013.822002https://doi.org/10. 1080/00288233.2013.822002

DairyNZ，2017. Facts \& Figures. https://doi. org/10.3390/agriculture7100081

DairyNZ, 2021. Pastoral 21 report. https://www. dairynz.co.nz/about-us/research/pastoral-21.

de Klein CAM, Ledgard SF (2001). An analysis of environmental and economic implications of nil and restricted grazing systems designed to reduce nitrate leaching from New Zealand dairy farms. I. Nitrogen losses. New Zealand Journal of Agricultural Research 44, 201-215. https://doi.org/10.1080/0028 8233.2001.9513478

Glassey CB, 2019. Pads and Pasture growth gains. Inside Dairy, May 2019 DairyNZ Ltd., New Zealand. www.dairynz.co.nz/news/pads-and-pasture-growthgains

Newman M, Journeaux P, 2015.The economic and nutrient loss impacts of constructing and running cow housing facilities-a case study of five South Island freestall barns. Massey University, Palmerston North, New Zealand. https://www.massey.ac.nz/ flrc/ workshops/16/Manuscripts/Paper_Chrystal_1_2016. pdf

McQueen IPM, 1970. The effects of winter management on farm production, An assessment of the wintering trial on No 3, Dairy Unit, Massey University. Dairy farming Annual 20: 169-180. Massey University, Palmerston North, New Zealand. https://agris.fao.org/ agris-search/search.do?recordID=US201302394304

Thomson NA, and Laurence MR, 1992. The effect of duration of winter grazing on subsequent pasture growth. Dairy farming Annual, 44: 132-134. Massey University, Palmerston North, New Zealand. http:// dx.doi.org/10.1071/AR00063

Woodford, 2018. Occasional report No 31. Massey University, Palmerston North, New Zealand. http:// flrc.massey.ac.nz/publications.html. 